\title{
Analisis Kebutuhan Tenaga di Instalasi Farmasi RS Universitas Muhammadiyah Malang Tahun 2016
}

\author{
Noor Annisa Susanto*, Muhammad Mansur, Thontowi Djauhari \\ * Penulis Korespondensi: noorannisasintara@gmail.co.id \\ Rumah Sakit Universitas Muhammadiyah Malang, Indonesia \\ INDEXING \\ Keywords: \\ Human resources; \\ WISN; \\ Workload;

\begin{abstract}
A B S T R A C T
The success of pharmaceutical service standard at Universitas Muhammadiyah Malang Hospital is supported by human resources availability. Therefore, it is necessary to conduct a need analysis on pharmaceutical personnels based on their workload. This research aims to determine the personnel need in pharmacy installation of Universitas Muhammadiyah Malang Hospital based on its workload. It was a descriptive research with observation and interview as primary data and annual report as secondary data. The WISN ratio of 0.4 was gained by comparing the condition in the field with the WISN calculation results. The ratio $<1$ means that the current amount of human resources is smaller than the requirement standard. It indicates the pharmacy installation condition in Universitas Muhammadiyah Malang Hospital is currently lack of human resources
\end{abstract}

Kata kunci:

Sumber daya

manusia;

WISN;

Beban kerja;
Keberhasilan standar pelayanan kefarmasian di Rumah Sakit Universitas Muhammadiyah didukung oleh ketersediaan sumber daya manusia. Karena itu perlu dilakukan analisis kebutuhan tenaga farmasi berdasarkan beban kerja. Tujuan penelitian ini untuk mengetahui kebutuhan SDM di IFRS UMM berdasarkan beban kerjanya. Penelitian ini merupakan penelitian deskriptif dengan metode pengumpulan data primer melalui observasi dan wawancara serta data sekunder berupa laporan bulanan maupun tahunan. Rasio WISN dihitung dengan membandingkan kondisi di lapangan dengan hasil perhitungan WISN. Hasil penelitian diperoleh nilai rasio WISN sebesar 0,4 . Rasio $<1$ dapat diartikan bahwa jumlah tenaga saat ini lebih kecil dibandingkan dengan tenaga yang dibutuhkan. Sehingga dapat dikatakan kondisi IFRS UMM saat ini kekurangan tenaga farmasi.

(C) 2017 JMMR. All rights reserved

\section{PENDAHULUAN}

Rumah Sakit Universitas Muhammadiyah Malang (RS UMM) merupakan rumah sakit umum tipe $\mathrm{C}$ dengan kapasitas 91 tempat tidur yang berada di bawah naungan Persyarikatan Muhammadiyah dan penyelenggaranya adalah Universitas Muhammadiyah Malang. RS UMM terletak di Desa Landungsari Kecamatan Dau Kabupaten Malang dengan akses jalan masuk melalui Jl. Raya Tlogomas No. 45 Kota Malang. Rumah sakit ini diresmikan pada tanggal 17 Agustus 2013 dengan izin operasional Nomor : 180/ 0006/ IORS/ 421.302/ 2013. Pelayanan yang diberikan terdiri dari layanan poliklinik dokter spesialis, dokter umum, dokter gigi, IGD, ICU, dan layanan penunjang lainnya. ${ }^{1}$

Kinerja Pelayanan RS UMM pada tahun 2015 dilihat dari indikator efisiensi RS yaitu BOR 77\% dan TOI 2 hari sudah sesuai dengan standar dalam Depkes 2005 yaitu BOR 60\%-85\% dan TOI 1-3 hari. Sedangkan
ALOS 5 hari dan BTO 54 kali belum sesuai dengan standar yaitu ALOS 6-9 hari dan BTO 40-50 kali. ${ }^{1}$

Salah satu pilar utama pelayanan yang dilakukan di rumah sakit adalah pelayanan obat atau farmasi. Menurut penelitian Suciati hampir 90\% pelayanan di rumah sakit menggunakan perbekalan farmasi, bahkan pemasukan rumah sakit sebesar $50 \%$ sebagian besar dari pengelolaan sediaan farmasi. ${ }^{2}$ Pelayanan kefarmasian di RS UMM dilakukan oleh Instalasi Farmasi Rumah Sakit (IFRS). IFRS UMM dipimpin oleh seorang apoteker sebagai kepala IFRS dibantu oleh 2 apoteker pendamping dan 18 tenaga teknis kefarmasian. Hal ini belum sesuai dengan standar dalam permenkes no. 56 tahun 2014 bahwa untuk RS tipe $\mathrm{C}$ minimal memiliki 8 apoteker. ${ }^{3}$

IFRS UMM terdiri dari tiga depo yaitu depo farmasi rawat inap rawat jalan, depo farmasi IGD dan depo farmasi OK. Pelayanan farmasi yang dilakukan IFRS UMM masih fokus pada kegiatan manajerial meliputi proses pemilihan, pengadaan, penyimpanan, pendistribusian dan 
administrasi. Kegiatan pemilihan perbekalan farmasi sesuai dengan formularium RS, namun saat ini formularium RS masih belum direvisi. Kegiatan Perencanaan berdasarkan ketersediaan stok perbekalan farmasi yang ada di gudang sedangkan perencanaan jangka panjang dengan periode tertentu belum dilakukan. Pengadaan, penerimaan, dan penyimpanan dilakukan oleh gudang farmasi. Setiap depo farmasi menyimpan dalam jumlah yang lebih kecil. Kegiatan pendistribusian ke depo farmasi dan unit lain di seluruh RS dilakukan oleh gudang farmasi, sedangkan pendistribusian ke pasien dilakukan oleh masing-masing depo farmasi. Kegiatan pemusnahan hingga saat ini belum pernah dilakukan, sedangkan kegiatan pengendalian dan admintrasi masih berupa pencatatan dan pelaporan rutin. Pelayanan farmasi klinik yang diberikan masih berupa pelayanan resep. Pelayanan farmasi klinik terkait penelusuran riwayat penggunaan obat, rekonsiliasi obat dan konseling masih terbatas pada pasien tertentu. Pelayanan informasi obat masih belum berjalan maksimal. Sedangkan pelayanan farmasi klinik lainnya seperti dispensing sediaan steril dan pemantauan obat dalam darah masih belum dilakukan.

Kinerja IFRS UMM sampai bulan juli 2016 dilihat dari indikator waktu tunggu non racikan membutuhkan waktu 9,2 menit, dan racikan 12,1 menit telah memenuhi target yaitu waktu tunggu non racikan $<30$ menit dan racikan < 60 menit. Indikator kepuasan pelanggan $99,96 \%$ telah memenuhi target $>80 \%$. Sedangkan indikator kepatuhan penulisan resep sesuai formularium saat ini belum dilakukan. ${ }^{4}$ Indikator tidak ada kejadian kesalahan pemberian obat pada bulan Juni telah tercapai 100\%. Berdasarkan Kepmenkes no. 129 tahun 2008 nilai indikator di IFRS UMM sebesar $80 \%$ sudah sesuai standar. $^{5}$

Menurut Permenkes Nomor 58 tahun 2014 tentang Standar Pelayanan Farmasi di RS kebijakan pengelolaan sediaan farmasi, alat kesehatan dan bahan medis habis pakai harus dilaksanakan secara multi disiplin, terkoordinir dan menggunakan proses yang efektif untuk menjamin kendali mutu dan biaya. IFRS sebagai satusatunya penyelenggara pelayanan kefarmasian termasuk pembuatan formularium, pengadaan dan pendistribusian sediaan farmasi, alat kesehatan dan bahan medis habis pakai. $^{6}$

Dari penjabaran tersebut sebagian penyelenggaraan pelayanan kefarmasian di RS UMM masih ada yang belum sesuai dengan standar. Keberhasilan penyelenggaraan standar pelayanan kefarmasian di rumah sakit harus didukung oleh ketersediaan sumber daya kefarmasian salah satunya sumber daya manusia
(SDM). ${ }^{6}$ Ketersediaan SDM farmasi selain mengikuti regulasi yang ada juga harus menyesuaikan dengan kebutuhan rumah sakit. Sehingga perlu perencanaan kebutuhan SDM yang tepat sesuai dengan kebutuhan ${ }^{7}$, oleh karena latar belakang tersebut peneliti ingin melakukan analisis kebutuhan tenaga farmasi di instalasi farmasi rumah sakit UMM.

Pemenuhan SDM merupakan hal penting bagi suatu institusi atau perusahaan. Kelebihan tenaga menyebabkan beban biaya menjadi besar dan tidak efisien dalan pengelolaan keuangan. Sedangkan kekurangan tenaga akan meningkatkan beban kerja SDM yang dapat mempengaruhi kualitas pelayanan. ${ }^{7,8}$

Ketersediaan SDM farmasi selain mengikuti regulasi yang ada juga harus menyesuaikan dengan kebutuhan rumah sakit. Sehingga perlu perencanaan SDM yang tepat sesuai dengan kebutuhan. ${ }^{9}$ Kebutuhan SDM tersebut didasarkan pada beban kerjanya, hal ini untuk mengetahui kapasitas kerja sehingga didapatkan keseimbangan antara tenaga dan beban kerja. ${ }^{10}$ Oleh karena latar belakang tersebut peneliti ingin melakukan analisis kebutuhan tenaga farmasi di IFRS UMM.

\section{METODE PENELITIAN}

Penelitian ini merupakan penelitian deskriptif untuk mengetahui kebutuhan tenaga farmasi guna meningkatkan pelayanan kefarmasian di instalasi farmasi rumah sakit universitas Muhammadiyah Malang (RS UMM). Data awal diperoleh melalui studi pendahuluan untuk mengidentifikasi permasalahan yang ada di rumah sakit universitas Muhammadiyah Malang. Dari identifikasi permasalahan kemudian discoring melalui forum Focus Group Discussion (FGD) yang dihadiri Kabid dan Kasubid RS UMM. FGD merupakan suatu metode yang dapat digunakan untuk menggumpulkan data secara kualitatif. ${ }^{11}$ FGD juga berfungsi sebagai suatu alat penelitian dalam dunia kesehatan dan perspektif medis. ${ }^{12}$ Hasil musyawarah dalam FGD disepakati bahwa 5 masalah di instalasi farmasi merupakan dampak dari sistem manajemen farmasi yang berlum berjalan maksimal. Sehingga masalah ini merupakan prioritas masalah yang selanjutnya akan dicari akar permasalahan dengan metode diagram tulang ikan (fish bone). Hasil analisis akar masalah dengan diagram tulang ikan diperoleh beberapa alternatif solusi untuk mengurangi dampak dari manajemen farmasi yang belum maksimal. Alternatif solusi tersebut didiskusikan kembali dan disepakati alternatif solusi yang memungkinkan adalah melakukan analisis kebutuhan tenaga farmasi di instalasi farmasi rumah sakit universitas muhammadiyah Malang (IFRS UMM). 
Penelitian ini menggunakan data kegiatan rumah sakit yang diambil dari laporan tahunan RS UMM, data rekam medis, laporan bulanan IFRS UMM, wawancara dengan beberapa staf terkait dan survei kegiatan di IFRS UMM. Instrument yang digunakan dalam penelitian ini adalah perhitungan kebutuhan tenaga dengan metode WISN. WISN bermanfaat untuk menghitung kebutuhan saat ini dan masa mendatang dan dapat mengidentifikasi seberapa besar beban kerja SDM kesehatan. ${ }^{13}$ Perhitungan tenaga dengan metode WISN tediri dari lima langkah yaitu memilih kategori SDM, menghitung waktu kerja tersedia (WKT) dengan rumus sebagai berikut:

\section{$\mathbf{W K T}=\mathbf{K}-(\mathbf{L}+\mathbf{M}+\mathbf{P}) \times \mathbf{E}$}

Yang mana $\mathrm{K}$ adalah jumlah hari kerja, $\mathrm{L}$ adalah jumlah hari libur nasional, $\mathrm{M}$ adalah jumlah hari cuti tahunan, $\mathrm{P}$ adalah jumlah hari tidak masuk kerja karena sakit, pelatihan atau lainnya, semua dihitung dalam setahun. Sedangkan E adalah waktu kerja efektif dalam satu hari. Standar beban kerja disusun berdasarkan ratarata waktu yang dibutuhkan untuk satu kegiatan dan waktu kerja tersedia dalam setahun.

Standar beban kerja $=\frac{\text { Waktu kerja tersedia }}{\text { rata }- \text { rata } \text { waktu }}$

Menghitung faktor-faktor kelonggaran bertujuan mengetahui waktu untuk menyelesaikan kegiatan diluar kegiatan pokok. Adapun rumusnya sebagai berikut:

\section{$\frac{\text { Rata }- \text { rata waktu per faktor kelonggaran }}{\text { Waktu kerja tersedia }(W K T)}$}

Tahap terakhir adalah menghitung kebutuhan tenaga dengan rumus:

\section{$\frac{\text { Kuantitas Kegiatan Pokok }}{\text { Standar Beban Kerja }}+$ Standar kelonggaran}

Kuantitas kegiatan pokok adalah jumlah suatu kegiatan pokok yang dilakukan dalam setahun dikali waktu yang dibutuhkan untuk melakukan kegiatan tersebut. Hasil perhitungan kebutuhan tenaga dengan metode WISN akan dibandingkan dengan tenaga yang ada sehingga diperoleh rasio WISN. ${ }^{14-16}$

\section{HASIL DAN PEMBAHASAN}

Perhitungan tenaga dengan metode WISN di IFRS UMM disesuaikan dengan pelayanan di setiap sub unit yaitu : Pelayanan rawat jalan dan rawat inap, pelayanan IGD, pelayanan kamar operasi dan gudang farmasi. Perhitungan WKT di IFRS UMM dalam setahun dengan 8 jam sehari selama 6 hari dalam seminggu dikurangi libur nasional, cuti bersama, pelatihan dan kemungkinan izin diperoleh WKT sebesar 2.168 jam atau 130.080 menit dalam setahun. Standar kelonggaran untuk kegiatan rapat, operan dan istirahat adalah sebesar 0,174. Hasil perhitungan kebutuhan tenaga farmasi untuk meningkatkan pelayanan kefarmasian di IFRS UMM adalah sebagai berikut :

Tabel 1. Hasil Perhitungan Kebutuhan Tenaga Farmasi Pelayanan Rawat Jalan dan Rawat Inap di IFRS UMM dengan Metode WISN Tahun 2016

\begin{tabular}{|c|c|c|c|c|}
\hline No. & Kegiatan Pokok & Standar Beban Kerja & Kuantitas & Kebutuhan \\
\hline & Perencanaan dan Pengadaan & & & \\
\hline 1. & Mengecek stok perbekalan farmasi yang tersedia & 8750 & 1560 & 0.178 \\
\hline \multirow[t]{2}{*}{3.} & Mengambil barang di gudang farmasi & 4375 & 3120 & 0.713 \\
\hline & Penerimaan & & & \\
\hline 5. & Melakukan penataan perbekalan farmasi & 4375 & 3120 & 0.713 \\
\hline \multirow[t]{2}{*}{6.} & Labeling obat-obat LASA dan Hight Alert & 8750 & 1560 & 0.178 \\
\hline & Pendistribusian & & & \\
\hline 7. & $\begin{array}{l}\text { Menerima, mengecek, menghargai dan memberikan } \\
\text { nomor antrian pasien rawat jalan }\end{array}$ & 43750 & 189582 & 4.333 \\
\hline 10. & Mengemas obat jadi dan memberi etiket & 43750 & 207846 & 4.751 \\
\hline 11. & Meracik obat & 13125 & 24500 & 1.867 \\
\hline 12. & Mengecek kesesuaian obat dan resep & 43750 & 207846 & 4.751 \\
\hline
\end{tabular}


Lanjutan Tabel 1. Hasil Perhitungan Kebutuhan Tenaga Farmasi Pelayanan Rawat Jalan dan Rawat Inap di IFRS UMM dengan Metode WISN Tahun 2016

\begin{tabular}{|c|c|c|c|c|}
\hline No. & Kegiatan Pokok & Standar Beban Kerja & Kuantitas & Kebutuhan \\
\hline 13. & Menyerahkan obat kepada pasien rawat jalan & 43750 & 207846 & 4.751 \\
\hline 14 & $\begin{array}{l}\text { Serah terima kepada perawat ruangan untuk obat } \\
\text { pasien rawat inap }\end{array}$ & 43750 & 18267 & 0.418 \\
\hline \multirow[t]{2}{*}{15} & Mengembalikan obat retur & 13125 & 6090 & 0.464 \\
\hline & Monitoring dan Evaluasi & & & \\
\hline 16 & Mengumpulkan dan memilah resep & 8750 & 5475 & 0.626 \\
\hline 17 & Membuat laporan suhu ruangan dan suhu kulkas & 26250 & 1825 & 0.070 \\
\hline 18 & Membuat laporan jumlah lembar resep yang dilayani & 13125 & 3650 & 0.278 \\
\hline 19 & membuat laporan narkotik dan psikotropik & 13125 & 3650 & 0.278 \\
\hline 20 & membuat laporan penulisan obat generic & 13125 & 3650 & 0.278 \\
\hline 21 & membuat laporan penulisan resep sesuai formularium & 13125 & 3650 & 0.278 \\
\hline 22 & Membuat laporan medication error & 13125 & 3650 & 0.278 \\
\hline 23 & membuat laporan jumlah pendapatan & 13125 & 3650 & 0.278 \\
\hline 24 & $\begin{array}{l}\text { membuat laporan perbekalan farmasi yang hampir } \\
\text { kadaluarsa }\end{array}$ & 13125 & 40 & 0.003 \\
\hline 25 & Survei waktu tunggu obat racikan dan nonracikan & 2187.5 & 720 & 0.329 \\
\hline 26 & $\begin{array}{l}\text { Membuat laporan waktu tunggu pelayanan obat jadi } \\
\text { dan racikan }\end{array}$ & 4375 & 360 & 0.082 \\
\hline 27 & $\begin{array}{l}\text { Melakukan evaluasi persediaan yang jarang } \\
\text { digunakan }\end{array}$ & 4375 & 120 & 0.027 \\
\hline 28 & Melakukan evaluasi death stock & 4375 & 120 & 0.027 \\
\hline 29 & Melakukan survei kepuasan pasien & 2187.5 & 720 & 0.329 \\
\hline 30 & Membuat laporan kepuasan pasien & 4375 & 360 & 0.082 \\
\hline 31 & Stok opname & 1093.75 & 480 & 0.439 \\
\hline \multirow[t]{2}{*}{32} & Merekap laporan harian menjadi laporan bulanan & 2187.5 & 720 & 0.329 \\
\hline & Kegiatan Farmasi Klinis & & & \\
\hline 33 & Pengkajian resep & 43750 & 207846 & 4.751 \\
\hline 34 & Penelusuran riwayat penggunaan obat & 43750 & 207846 & 4.751 \\
\hline 35 & Rekonsiliasi Obat & 43750 & 207846 & 4.751 \\
\hline 36 & Pelayanan informasi obat & 4375 & 360 & 0.082 \\
\hline 37 & Konseling Pasien Rawat Jalan & 13125 & 31597 & 2.407 \\
\hline 38 & Visite & 13125 & 3044.5 & 0.232 \\
\hline 39 & Pemantauan terapi obat & 26250 & 17320.5 & 0.660 \\
\hline 40 & Monitoring efek samping obat & 26250 & 17320.5 & 0.660 \\
\hline \multirow[t]{4}{*}{41} & Evaluasi penggunaan obat & 26250 & 17320.5 & 0.660 \\
\hline & Sub Kebutuhan Tenaga & & & 46.896 \\
\hline & Standar Kelonggaran & & & 0.174 \\
\hline & Kebutuhan Tenaga & & & 47.070 \\
\hline
\end{tabular}

Dari tabel 1 diketahui aktivitas atau kegiatan pokok pelayanan farmasi rawat jalan dan rawat inap berjumlah 41 kegiatan. Berdasarkan perhitungan kebutuhan tenaga dengan metode WISN didapatkan total kebutuhan tenaga farmasi untuk melakukan pelayanan farmasi rawat jalan dan rawat inap sebanyak 47 orang.

Tabel 2. Hasil Perhitungan Kebutuhan Tenaga Farmasi Pelayanan Farmasi Instalasi Gawat Darurat RS UMM dengan Metode WISN Tahun 2016

\begin{tabular}{llrrr}
\hline No. & Kegiatan Pokok & Standar Beban Kerja & Kuantitas & Kebutuhan \\
\hline $\mathbf{1}$ & Mengecek stok perbekalan farmasi yang tersedia & 13152 & 520 & 0.040 \\
$\mathbf{2}$ & Melakukan defecta perbekalan farmasi online & 13152 & 520 & 0.040 \\
$\mathbf{3}$ & Mengambil barang di gudang & 4384 & 1560 & 0.356 \\
\hline
\end{tabular}


Lanjutan Tabel 2. Hasil Perhitungan Kebutuhan Tenaga Farmasi Pelayanan Farmasi Instalasi Gawat Darurat RS UMM dengan Metode WISN Tahun 2016

\begin{tabular}{|c|c|c|c|c|}
\hline No. & Kegiatan Pokok & Standar Beban Kerja & Kuantitas & Kebutuhan \\
\hline & Penerimaan & & & \\
\hline \multirow[t]{2}{*}{4} & Mengecek perbekalan farmasi yang dambil & 13152 & 520 & 0.040 \\
\hline & Penyimpanan & & & \\
\hline 5 & Penataan perbekalan farmasi & 8768 & 780 & 0.089 \\
\hline \multirow[t]{2}{*}{6} & Labeling obat LASA dan Hight Alert & 13152 & 520 & 0.040 \\
\hline & Pendistribusian & & & \\
\hline 7 & $\begin{array}{l}\text { Menerima,mengecek, menghargai dan mengentri resep } \\
\text { IGD }\end{array}$ & 43840 & 52762.619 & 1.204 \\
\hline 8 & Konfirmasi masalah resep pada dokter & 26304 & 263.81309 & 0.010 \\
\hline 9 & Mengecek kesesuaian obat dan resep & 43840 & 52764 & 1.204 \\
\hline \multirow[t]{2}{*}{10} & Mengecek emergency kit & 26304 & 1825 & 0.069 \\
\hline & Monitoring dan Evaluasi & & & \\
\hline 11 & Stok opname & 4384 & 120 & 0.027 \\
\hline \multirow[t]{2}{*}{12} & Membuat laporan bulanan & 4384 & 360 & 0.082 \\
\hline & Kegiatan Farmasi Klinis & & & \\
\hline \multirow[t]{4}{*}{13} & Rekonsiliasi Obat & 43840 & 52764 & 1.204 \\
\hline & Sub Kebutuhan Tenaga & & & 4.402 \\
\hline & Standar Kelonggaran & & & 0.174 \\
\hline & Kebutuhan Tenaga & & & 4.576 \\
\hline
\end{tabular}

Dari tabel 2 diatas diketahui aktivitas pelayanan farmasi di instalasi gawat darurat (IGD) berjumlah 13 kegiatan. Berdasarkan perhitungan kebutuhan tenaga dengan metode WISN didapatkan total kebutuhan tenaga farmasi untuk melakukan pelayanan farmasi IGD sebanyak 5 orang.

Tabel 3. Hasil Perhitungan Kebutuhan Tenaga Farmasi Pelayanan Farmasi Kamar Operasi RS UMM dengan Metode WISN Tahun 2016

\begin{tabular}{|c|c|c|c|c|}
\hline No & Kegiatan Pokok & $\begin{array}{c}\text { Standar Beban } \\
\text { Kerja }\end{array}$ & Kuantitas & Kebutuhan \\
\hline & Perencanaan dan Pengadaan & & & \\
\hline 1 & Mengecek stok perbekalan farmasi yang tersedia & 13152 & 520 & 0.040 \\
\hline 2 & Melakukan defecta perbekalan farmasi online & 13152 & 520 & 0.040 \\
\hline \multirow[t]{2}{*}{3} & Mengambil barang di gudang farmasi & 4384 & 1560 & 0.356 \\
\hline & Penerimaan & & & \\
\hline \multirow[t]{2}{*}{4} & Mengecek perbekalan farmasi yang diambil & 13152 & 520 & 0.040 \\
\hline & Penyimpanan & & & \\
\hline 5 & Melakukan penataan perbekalan farmasi & 8768 & 780 & 0.089 \\
\hline \multirow[t]{2}{*}{6} & Labeling obat LASA dan Hight Alert & 13152 & 520 & 0.040 \\
\hline & Pendistribusian & & & \\
\hline 7 & Menerima,mengecek, menghargai dan mengentri resep IGD & 26304 & 3970 & 0.151 \\
\hline 8 & Konfirmasi masalah resep kepada dokter & 26304 & 11.91 & 0.000 \\
\hline \multirow[t]{2}{*}{9} & Mengecek kesesuaian obat dan resep & 26304 & 3970 & 0.151 \\
\hline & Monitoring dan Evaluasi & & & \\
\hline 10 & Stok opname & 4384 & 120 & 0.027 \\
\hline \multirow[t]{4}{*}{11} & Membuat laporan bulanan & 4384 & 360 & 0.082 \\
\hline & Sub Kebutuhan Tenaga & & & 1.015 \\
\hline & Standar Kelonggaran & & & 0.174 \\
\hline & Kebutuhan Tenaga & & & 1.189 \\
\hline
\end{tabular}


Dari tabel 3 diatas diketahui aktivitas pelayanan farmasi kamar operasi berjumlah 11 kegiatan. Berdasarkan perhitungan kebutuhan tenaga dengan metode WISN didapatkan total kebutuhan tenaga farmasi untuk melakukan pelayanan farmasi IGD sebanyak 1 orang.

Tabel 4. Hasil Perhitungan Kebutuhan Tenaga Farmasi Pelayanan Gudang Farmasi RS UMM dengan Metode WISN Tahun 2016

\begin{tabular}{|c|c|c|c|c|}
\hline \multirow[b]{2}{*}{ No } & \multirow[b]{2}{*}{ Kegiatan Pokok } & \multicolumn{2}{|c|}{ Standar Beban } & \multirow[b]{2}{*}{ Kebutuhan } \\
\hline & & Kerja & Kuantitas & \\
\hline & Perencanaan dan Pengadaan & & & \\
\hline 1 & Perencanaan kebutuhan perbekalan farmasi & 2168 & 720 & 0.332 \\
\hline 2 & Mengecek stok perbekalan farmasi yang tersedia & 8672 & 1560 & 0.180 \\
\hline \multirow[t]{2}{*}{3} & Melakukan pemesanan ke PBF & 8672 & 1560 & 0.180 \\
\hline & Penerimaan & & & \\
\hline \multirow[t]{2}{*}{4} & Mengecek perbekalan farmasi yang datang & 8672 & 1560 & 0.180 \\
\hline & Penyimpanan & & & \\
\hline \multirow[t]{2}{*}{5} & Melakukan penataan perbekalan farmasi & 4336 & 3120 & 0.720 \\
\hline & Pendistribusian & & & \\
\hline 6 & Mengecek permintaan dari ruangan dan unit lain & 13008 & 3120 & 0.240 \\
\hline 7 & Mengentri perbekalan farmasi sesuai permintaan & 13008 & 3120 & 0.240 \\
\hline 8 & Menyiapkan perbekalan farmasi & 4336 & 9360 & 2.159 \\
\hline 9 & Mengecek kesesuaian dengan lembar permintaan & 13008 & 3120 & 0.240 \\
\hline \multirow[t]{3}{*}{10} & Menyerahkan perbekalan farmasi & 26016 & 1560 & 0.060 \\
\hline & Pemusnahan dan Penarikan Perbekalan Farmasi & 2168 & 60 & 0.028 \\
\hline & Monitoring dan Evaluasi & & & \\
\hline 11 & Stok opname & 2168 & 240 & 0.111 \\
\hline \multirow[t]{4}{*}{12} & Merekap laporan harian menjadi laporan bulanan & 2168 & 720 & 0.332 \\
\hline & Sub Kebutuhan Tenaga & & & 5.000 \\
\hline & Standar Kelonggaran & & & 0.174 \\
\hline & Kebutuhan Tenaga & & & 5.174 \\
\hline
\end{tabular}

Dari tabel 4 diatas diketahui aktivitas pelayanan di gudang farmasi berjumlah 21 kegiatan. Berdasarkan perhitungan kebutuhan tenaga dengan metode WISN didapatkan total kebutuhan tenaga farmasi untuk melakukan pelayanan farmasi IGD sebanyak 5 orang.

Tabel 5. Kebutuhan Tenaga Farmasi RS UMM Tahun 2016

\begin{tabular}{lc}
\hline Jenis Pelayanan Farmasi & Jumlah \\
\hline Pelayanan Rawat Jalan dan Rawat Inap & 47.070 \\
Pelayanan IGD & 4.576 \\
Pelayanan Kamar Operasi & 1.189 \\
Gudang Farmasi & 5.174 \\
TOTAL & $\mathbf{5 8 . 0 0 9}$ \\
\hline
\end{tabular}


Dari tabel 5 diatas berdasarkan perhitungan kebutuhan tenaga dengan metode WISN didapatkan total kebutuhan tenaga farmasi di IFRS UMM berjumlah 58 orang. Saat ini tenaga yang ada di instalasi farmasi dan gudang farmasi RS UMM berjumlah 24 orang sehingga bisa dihitung ratio WISN sebagai berikut:

Tabel 6. Kebutuhan Tenaga berdasarkan Ratio WISN

\begin{tabular}{lllll}
\hline $\begin{array}{l}\text { Tenaga yang ada } \\
(\text { A })\end{array}$ & $\begin{array}{l}\text { Kebutuhan } \\
\text { Tenaga (B) }\end{array}$ & $\begin{array}{l}\text { Kurang/Lebih (A- } \\
\text { B) }\end{array}$ & $\begin{array}{l}\text { WISN Ratio } \\
(\mathbf{A} / \mathbf{B})\end{array}$ & Keadaan Masalah Tenaga \\
\hline $\mathbf{2 4}$ & 58 & 34 & 0,4 & Kurang Staf \\
\hline
\end{tabular}

Berdasarkan perhitugan pada tabel 6 di atas, didapatkan ratio WISN tenaga farmasi di IFRS UMM tahun 2016 sebesar 0,4. Artinya adalah jumlah tenaga saat ini lebih kecil dibandingkan dengan jumlah tenaga yang dibutuhkan

\section{Pembahasan}

Menurut Kepmenkes RI Nomor 81 tahun 2004 tentang Pedoman Penyusunan Perencanaan Sumber Daya Manusia Kesehatan di Tingkat Propinsi, Kabupaten/Kota serta rumah sakit menyatakan bahwa metode perhitungan kebutuha SDM berdasarkan beban kerja (WISN) adalah suatu metode perhitunngan kebutuhan SDM kesehatan berdasarkan pada beban pekerjaan nyata yang dilaksanakan oleh tiap kategori SDM kesehatan pada tiap unit kerja di fasilitas kesehatan. ${ }^{17}$ Kelebihan metode WISN adalah mudah dioperasikan, mudah digunakan, secara teknis mudah diterapkan, komprehensif dan realistis. Berdasarkan perhitungan kebutuhan tenaga farmasi di IFRS UMM dengan metode WISN, di-dapatkan kebutuhan tenaga farmasi sebanyak 58 orang sedangkan saat ini tenaga farmasi yang ada masih ber-jumlah 24 orang. Hal ini menunjukkan IFRS UMM masih membutuhkan tenaga farmasi sebanyak 34 orang. Jika dilihat dari hasil perhitungan maka jumlah tenaga yang tersedia baru memenuhi $42 \%$ dari total kebutuhan tenaga, kondisi ini dapat mengakibatkan pengaruh buruk bagi pelayanan kefarmasian karena menurut Nurul beban kerja yang berlebih dapat mengakibatkan stress kerja yang berakibat buruk terhadap keselamatan pasien. ${ }^{15}$

Berdasarkan perhitungan rasio WISN, didapatkan ratio WISN tenaga farmasi di IFRS UMM tahun 2016 sebesar 0,4 . Artinya adalah jumlah tenaga saat ini lebih kecil dibandingkan dengan jumlah tenaga yang dibutuhkan untuk menjalankan beban kerja yang meningkat karena peningkatan pelayanan kefarmasian dalam rangka persiapan akreditasi rumah sakit. Semakin kecil rasio WISN, semakin besar tekanan beban kerja. Rasio WISN yang kecil menunjukkan bahwa jumlah tenaga farmasi saat ini lebih kecil daripada yang dibutuhkan. Sebaliknya rasio WISN yang besar (lebih dari 1) menunjukkan adanya kelebihan tenaga apabila dibandingkan dengan beban kerja. ${ }^{13}$ Ratio WISN yang semakin kecil menunjukkan beban kerja dari tenaga farmasi semakin besar. Hal ini dapat mengakibatkan stres kerja yang bisa mengakibatkan kelelahan tenaga farmasi dan memungkinkan memicu timbulnya konflik. Ini didukung oleh penelitian Hariyono yang menunjukkan bahwa ada hubungan yang signifikan antara beban kerja dan tingkat kelelahan kerja, adanya hubungan yang signifikan antara stres kerja dan kelelahan kerja serta adanya hubungan yang signifikan antara konflik dan tingkat kelelahan kerja. ${ }^{18}$

Pernyataan tersebut juga didukung oleh penelitian lain yang dilakukan oleh Sitepu menunjukkan bahwa ada pengaruh antara beban kerja terhadap kinerja namun tidak signifikan. Ketidaksignifikan tersebut kemungkinan karena masih belum meratanya pembagian beban kerja diantara tenaga kerja. ${ }^{19}$ Hal ini menunjukkan bahwa perlu adanya penambahan tenaga farmasi untuk meningkatkan pelayanan kefarmasian di IFRS UMM. Kekurangan dalam penelitian ini adalah belum dilakukan perhitungan berdasarkan jenis tenaga.

\section{SIMPULAN}

Hasil perhitungan kebutuhan tenaga farmasi di IFRS UMM dengan metode WISN membutuhkan tenaga farmasi sebanyak 58 orang. Saat ini tenaga yang tersedia adalah sebanyak 24 orang, sehingga penulis menyarankan perlu adanya penambahan tenaga farmasi untuk meningkatkan pelayanan kefarmasian di Instalasi Farmasi Rumah Sakit Universitas Muhammadiyah Malang.

\section{DAFTAR PUSTAKA}

1. RS UMM. Laporan Tahunan RS UMM Tahun 2015. Malang: 2015. 
2. Suciati S, Adisasmito WB, Wiku B. Analisis perencanaan obat berdasarkan $A B C$ indeks kritis di instalasi farmasi. Jurnal Manajemen Pelayanan Kesehatan. 2006;9(1):19-26.

3. Permenkes RI No.56 Tahun 2014 Klasifikasi dan perizinan rumah sakit, (2014).

4. IFRS UMM. Laporan Bulanan Instalasi Farmasi Bulan Juli. 2016.

5. Kepmenkes:No.129/Menkes/SK/II/2008 Tentang Standar Pelayanan Minimal Rumah Sakit, (2008).

6. Permenkes: Nomor 58 Tahun 2014 Tentang Standar Pelayanan Kefarmasian di Rumah Sakit, (2014).

7. Beswick S, Hill PD, Anderson MA. Comparison of nurse workload approaches. Journal of Nursing Management. 2010;18(5):592-8.

8. MacPhee M, Ellis J, McCutheon AS. Nurse staffing and patient safety. Canadian Nurse. 2006;102(8).

9. Ilyas Y. Perencanaan SDM Rumah Sakit, Teori, Metoda dan Formula Cetakan Ketiga. Depok: FKM UI; 2011.

10. Hendianti GN. Gambaran Beban Kerja Perawat Pelaksana Unit Instalasi Gawat Darurat Rumah Sakit Muhammadiyah Bandung. Students e-Journal. 2012;1(1):31.

11. Colucci E. "Focus groups can be fun": The use of activity-oriented questions in focus group discussions. Qualitative Health Research. 2007;17(10):1422-33.

12. Wong LP. Focus group discussion: a tool for health and medical research. Singapore Med J. 2008;49 (3):256-60.
13. RI D, GTZ. Perlengkapan Kerja WISN untuk Memperbaiki Perencanaan dan Manajemen Tenaga Kerja Kesehatan dalam Sistem Kesehatan yang Disentralisasi. Jakarta2009.

14. Shipp PJ, Organization WH. Workload indicators of staffing need (WISN): a manual for implementation. 1998.

15. Rubbiana NI. Analisis beban kerja dan kebutuhan tenaga perawat pelaksana dengan metode Workload Indicator Staff Need (WISN) di Instalasi Rawat Inap Tulip RSUD Kota Bekasi Tahun 2015. 2015.

16. Cahyono A, Sudarmaningtyas P, Nurcahyawati V. Rancang Bangun Aplikasi Analisis Perencanaan Kebutuhan Tenaga Kesehatan Menggunakan Metode Wisn (Studi Kasus Rsia Prima Husada). Jurnal JSIKA. 2016;5 (3).

17. Pedoman Penyusunan Perencanaan Sumber Daya Manusia Kesehatan, (2004).

18. Hariyono W, Suryani D, Wulandari Y. Hubungan antara beban kerja, stres kerja dan tingkat konflik dengan kelelahan kerja perawat di rumah sakit islam Yogyakarta PDHI Kota Yogyakarta. Jurnal Kesehatan Masyarakat (Journal of Public Health). 2012;3(3):18697.

19. Sitepu AT. Beban kerja dan motivasi pengaruhnya terhadap kinerja karyawan pada PT. Bank Tabungan Negara Tbk Cabang Manado. Jurnal Riset Ekonomi, Manajemen, Bisnis Dan Akuntansi. 2013;1(4). 